\title{
Ekranisasi AR PASUA PA: dari Seni Pertunjukan ke Seni Digital sebagai Upaya Pemajuan Kebudayaan
}

\author{
Sri Rustiyanti ${ }^{1}$, Wanda Listiani ${ }^{2}$, Fani Dila Sari ${ }^{3}$, IBG. Surya Peradantha ${ }^{4}$ \\ ${ }^{1}$ Program Studi Antropologi Budaya, Fakultas Budaya dan Media \\ Institut Seni Budaya Indonesia (ISBI) Bandung Jl. Buahbatu 212 Bandung 40265 Indonesia \\ ${ }^{2}$ Program Studi Seni Kriya, Fakultas Seni Rupa dan Desain \\ Institut Seni Budaya Indonesia (ISBI) Bandung Jl. Buahbatu 212 Bandung 40265 Indonesia \\ ${ }^{3}$ Program Studi Seni Teater, Institut Seni Budaya Indonesia (ISBI) Aceh Jl. Transmigrasi No. I, Gampong \\ Bukit Meusara, Kota Jantho-Aceh Besar 23911 \\ ${ }^{4}$ Program Studi Seni Tari, Institut Seni Budaya Indonesia (ISBI) Tanah Papua. Jl. Raya Sentani KM. 17,8 \\ Waena, Kota Jayapura, 99351 Indonesia \\ ${ }^{1}$ rustiyantisri@yahoo.com
}

Ekranisasi adalah transformasi dari karya sastra ke bentuk film, yang berarti layar. Dengan meminjam istilah ekranisasi dari bahasa Prancis ini, peneliti akan mengangkat atau memindahkan sebuah karya seni pertunjukan ke dalam seni digital yaitu Augmented Reality. Visualisasi virtual pertunjukan augmented reality merupakan bentuk seni baru, yang memang ini bertujuan untuk membuat penikmatnya merasa seolah berada di tengah suatu ilusi akan realita yang digambarkan melalui sebuah alat interaktif antara virtual dan realita. Ekranisasi sebagai upaya Pemajuan Kebudayaan untuk melestarikan kesenian tradisi dapat mengikuti perkembangan zaman, di mana konsep estetik pun mengikuti perkembangan setiap zaman. Perubahan yang terjadi dapat pengurangan, penambahan, dan variatif yang memungkinkan terjadi dalam proses transformasi dari karya seni pertunjukan ke seni digital. Ekranisasi memungkinkan terjadinya variasi-variasi tertentu, misal dalam ranah ide karya visual, gaya penceritaan, media yang digunakan, persoalan penonton, dan durasi waktu pemutaran. Alasan ekranisasi tersebut antara lain karena Tari Cikeruhan, Tari Guel, dan Tari Wor cukup dikenal oleh masyarakat pendukungnya, sehingga masyarakat pada umumnya sudah tak asing lagi dengan ketiga tarian tersebut. Metode yang digunakan pada penelitian ini adalah metode kuantilatif, yaitu memadukan metode kuantitatif dan kualitatif. Metode kuantitatif untuk mendefinisikan pola-pola penggunaan foto green screen profil penari Papua, Sunda, dan Aceh dalam upaya pembuatan secara virtual art dan realtime untuk disinkronisasikan, sedangkan metode kualitatif memberikan deskripsi eksploratif tentang bahasa visual yang digunakan pada foto green screen profil penari Papua, Sunda, dan Aceh. Hasil penelitian ini adalah sebagai salah satu alternatif terobosan untuk melestarikan dan merekonstruksi kembali seni tradisi dengan memanfaatkan teknologi di era indutri 4.0 sebagai upaya untuk Pemajuan Kebudayaan.

Kata kunci: ekranisasi, augmented reality, seni digital, seni tradisi, pemajuan kebudayaan.

\section{AR PASUA PA Ecranisation: From Performing Arts to Digital Arts as an Effort to Cultural Objects}

Ecranization is the transformation of literary works into film forms, which means screens. By borrowing the term ekranisasi from French, the researcher will lift or move the performing art into digital art, namely Augmented Reality. Virtual visualization of augmented reality shows is a new art form, which indeed aims to make the audience feel as if they are in the middle of an illusion of reality which is portrayed through an interactive tool between virtual and reality. Ecranization as an effort of cultural advancement to preserve traditional arts, so it can keep up with the times, where the aesthetic concept follows the development of each era. Changes that occur can be reduced, added, and varied which allows to occur in the process of transformation from artwork to digital art. Ecranization allows certain variations, for example in the realm of visual work ideas, the style of storytelling, the media used, the audience's problems, and the duration of playback time. The reason for ecranization was partly because of Cikeruhan Dance, Guel Dance, and Wor Dance were well known by the supporting community, so public was familiar with those dances. The method used in this study was quantilative which combines quantitative and qualitative methods. Quantitative methods was used for defining patterns of the use of green screen photos of Papuan, Sundanese and Aceh dancers in an effort to create virtual art and real time for synchronization, whereas the qualitative method 
was used for providing an explorative description of the visual language used in the green screen photo of Papuan, Sundanese, and Aceh dancers. The results of this study are as one of the alternative breakthroughs to preserve and reconstruct traditional arts by utilizing technology in the industrial era 4.0 as an effort of Cultural Advancement.

Keywords: ecranization, augmented reality, digital art, traditional art, cultural advancement.

Proses Review : 1 - 20 Mei 2021, Dinyatakan Lolos: 31 Mei 2021

\section{PENDAHULUAN}

Setiap daerah memiliki identitas dan karakteristik tersendiri yang menjadi kearifan lokal yang beragam. Begitu juga dengan Papua, Sunda, dan Aceh yang menjadi subjek mater dalam wilayah kajian penelitian Konsorsium Kemenristekdikti ini. Tanah Papua yang dikenal dengan identitas 'Burung Cendrawasih', Sunda sebagai 'Tanah Parahyangan', dan Aceh sebagai 'Serambi Mekah', memiliki local genius yang tersendiri. Penelitian ini bertujuan untuk ekranisasi sebagai transformasi seni pertunjukan ke seni digital dengan menggali nilainilai yang ada dalam kesenian Papua, Sunda, dan Aceh (disingkat Pasua), agar nilai-nilai (intangible) yang terkandung dalam kesenian Pasua tetap terjaga dengan baik. Kondisi nilai-nilai budaya dalam kearifan lokal dapat mengalami empat hal yang yang tak dapat dihindari, yaitu punah, bertahan, berubah, dan berkembang. Oleh karena itu, dalam pelestarian nilai-nilai yang terkandung dalam kesenian Pasua sangat penting untuk direkonstruksi kembali melalui seni media baru yaitu seni digital Augmented Reality (AR) Papua Sunda Aceh (Pasua) Performent Art (PA) disingkat menjadi AR Pasua PA.

Tulisan ini merupakan hasil Penelitian Konsorsium bidang Seni (KRUPT) dengan mengangkat tiga fenomena budaya yang ada di Nusantara yaitu Papua, Sunda, dan Aceh. Struktur dari ketiga wilayah territorial ini menjadi sebuah nama realitas virtual yang khas berupa Augmented Reality Pasua (Papua-Sunda-Aceh) Performance Arts di era revolusi industri 4.0. Augmented Reality Pasua (PapuaSunda-Aceh) Performance Arts, dalam tulisan ini disingkat menjadi AR Pasua PA, merupakan sebuah augmented reality real time synchronization dalam penciptaan seni pertunjukan 4.0. yang menggambarkan tentang siklus kehidupan manusia yang disimbolkan dengan matahari terbit di Papua, bersinar di Sunda, dan terbenam di Aceh. Indonesia adalah negara yang kaya akan keanekaragaman budaya dan etnis. Keanekaragaman budaya daerah tersebut merupakan potensi sosial yang dapat membentuk karakter dan citra budaya tersendiri pada masing-masing daerah, serta merupakan bagian penting bagi pembentukan citra dan identitas budaya suatu daerah. Di samping itu, keanekaragaman merupakan kekayaan intelektual dan kultural sebagai bagian dari warisan budaya yang perlu dilestarikan.
Seni pertunjukan di Indonesia berangkat dari suatu keadaan di mana ia tumbuh dalam lingkungan etnik yang berbeda satu sama lain. Dalam lingkungan etnik ini, adat, atau kesepakatan bersama yang turun temurun mengenai perilaku, mempunyai wewenang yang amat besar untuk menentukan rebah bangkitnya kesenian, termasuk seni pertunjukan (Sedyawati, 1986: 52). Indonesia memiliki pertunjukan tradisi cukup banyak dan bentuknya beragam, ini merupakan kekayaan intelektual bangsa yang tak akan pernah habis. Dalam proses pertumbuhannya, kesenian tradisi merupakan bagian dari kesenian rakyat yang diwariskan secara turun-temurun dari generasi ke generasi. Hal ini sesuai dengan apa yang dijelaskan oleh Yoety, bahwa kesenian tradisional adalah kesenian yang sejak lama turun temurun hidup dan berkembang pada suatu daerah, masyarakat etnik tertentu yang perwujudannya mempunyai peranan tertentu dalam masyarakat pendukungnya (1983: 13).

Seiring dengan perkembangan zaman di era industri 4.0 berbagai cabang seni mulai menjelma ke arah bentukbentuk seni yang lain. Seni sebagai hasil kreativitas manusia merupakan proses simbolis untuk memaknai realitas, di mana kreativitas seni sangat ditentukn oleh perubahan sosial dalam masyarakat (Seramasara, 2017: 179). Ekranisasi seni sering dilakukan oleh seniman sebagai kreativitas yang ingin ke luar dari kemapanan atau protes terhadap kepakeman untuk menciptakan seni-seni parodi. Pergeseran pola kehidupan masyarakat agraris menuju masyarakat industri secara langsung mempengaruhi perkembangan kehidupan, tak terkecuali seni. Memang seni itu sangat dinamis, adaptif, dan kondusif dengan tuntutan pertunjukan yang dinginkan. Saat ini, seringkali fenomena kesenian yang kita saksikan dalam bentuk yang lebih realistis. Seperti halnya dengan seni digital. Dengan kata lain, bahwa seni dibagi menjadi dua bentuk, yaitu konvensional (tradisi) dan digital. Keberagaman seni tradisi, seperti seni sastra, seni tari, seni musik, dan seni rupa. Salah satu seni yang dibahas dalam seni digital yaitu seni tari rakyat yang ada di Tanah Papua, Tanah Parahyangan, dan Aceh.

Semakin berkembangnya zaman kehidupan berubah, begitu pula dengan teknologi yang semakin berkembang juga dan menciptakan inovasi-inovasi baru yang dapat membantu kehidupan manusia menjadi lebih mudah. 
Banyak hal positif yang kita dapatkan dari perkembangan ini, salah satu contohnya adalah aplikasi di handphone yang dapat membantu manusia untuk memenuhi kebutuhan sehari-harinya, seperti seni digital yaitu augmented reality, aplikasi edit video, suara, musik, game, dan masih banyak lagi. Seni digital sendiri memiliki arti yaitu sebuah karya yang dibuat dengan teknologi digital atau yang disajikan dalam bentuk teknologi digital.

Akan tetapi, juga mendapatkan banyak hal negatif dengan adanya perkembangan yang terjadi sekarang. Salah satunya adalah seni tradisional yang mulai terlupakan, karena di zaman dan teknologi yang semakin berkembang ini manusia semakin terpukau dengan kehebatan teknologi, salah satunya adalah dengan film-film animasi karya Walt Disney, Dream Works, Pixar, dll. Selain itu manusia juga asik dengan dunianya sendiri, yaitu dunia gadget/ handphonenya, karena di dalam gadget/handphone manusia bisa mendapatkan apa yang mereka butuhkan dan apa yang mereka mau.

Banyak cara yang dapat digunakan untuk pelestarian nilai-nilai seni tradisi yang berkelanjutan, agar eksistensi bertahan dan terus berkelanjutan, salah satunya adalah melalui Pemajuan Kebudayaan sebagai upaya meningkatkan ketahanan budaya dan kontribusi budaya Indonesia di tengah peradaban dunia melalui Pelindungan, Pengembangan, Pemanfaatan, dan Pembinaan Kebudayaan (UU RI No. 5 Tahun 2017 tentang Pemajuan Kebudayaan). AR Pasua PA sebagai objek upaya dalam Pemajuan Kebudayaan (UU No. 5 Pasal 5). Adapun rekonstruksi pembuatan seni digital AR Pasua PA berdasarkan pada azas toleransi, keberagaman, kelokalan, lintas wilayah, partisipatif, manfaat, keberlanjutan, kebebasan berekspresi, keterpaduan, kesederajatan, dan gotong royong (UU No. 5 Pasal 3). Kearifan lokal memiliki nilai-nilai budaya yang mapan dalam kurun waktu yang cukup panjang, sedangkan kontemporer sebagai nilainilai budaya baru yang sedang mencari sosok kemapanan sebagai konsep yang akan menjamah di berbagai bidang seni, salah satunya adalah hasil penelitian ini adalah $A R$ Pasua PA.

Pengesahan Undang-Undang (UU) Nomor 5 Tahun 2017 tentang Pemajuan Kebudayaan membawa semangat baru dalam upaya pelindungan, pengembangan, pemanfaatan, dan pembinaan kebudayaan nasional. Setelah puluhan tahun merdeka, akhirnya Republik Indonesia memiliki sebuah panduan dalam upaya menjalankan amanat Pasal 32 Ayat 1 UUD 1945 untuk memajukan kebudayaan. Strategi Pemajuan Kebudayaan sebagai upaya agar generasi muda tidak melupakan akar budaya bangsa. Generasi penerus bangsa tidak boleh kehilangan jati diri sebagai bangsa Indonesia. Upaya-upaya ini penting dilakukan agar potensi budaya Indonesia bisa tergarap dengan baik. Dalam UU Pemajuan Kebudayaan ada 10 objek pemajuan kebudayaan (OPK), yaitu: tradisi lisan, manuskrip, adat istiadat, ritus, pengetahuan tradisonal, seni, bahasa, permainan rakyat, dan olahraga tradisional. 10 OPK ini merupakan tradisi yang turun-temurun, kalau di Minangkabau disebut sebagai pamenan anak nagari, yaitu kesenian tradisi yang tumbuh dan berkembang di tengah-tengah kehidupan masyarakat dimainkan dari rakyat, oleh rakyat, dan untuk rakyat yang dipertunjukkan untuk memperingati baik upacara keagamaan maupun sosial kemasyarakatan (Rustiyanti, 2015: 105).

Adapun upaya-upaya yang dilakukan AR Pasua PA sebagai strategi pelestarian dalam estetika dan kearifan lokal yang dimiliki oleh Papua, Sunda, dan Aceh dapat dilakukan oleh seluruh masyarakat pendukung baik dari seniman, pemerintah, maupun apresiator, melalui: a) Inventarisasi, dengan melakukan pendokumentasian, penelitian, dan pemanfaatan sarana teknologi. Langkah ini merupakan tahap pendataan untuk mengumpulkan semua fakta yang ada baik secara tekstualitas maupun kontekstialitasnya, yang dapat digunakan sebagai bahan referensi untuk menjelaskan bahwa kearifan lokal tersebut pernah ada, atau bahkan sudah punah, bertahan, berubah, dan berkembang; b) Konservasi, dilakukan untuk menjaga sebagai pemeliharaan secara teratur agar tidak terjadi kepunahan. Upaya ini dapat dilakukan secara periodik melalui kurikulum yang ada di Lembaga Pendidikan Formal, baik dari tingkat Sekolah Dasar hingga Perguruan Tinggi; c) Rekonstruksi, tahap ini jika suatu kesenian sudah mengalami kepunahan bersama pendukungnya yang biasanya sudah usia lanjut dan tidak ada pewarisnya yang meneruskannya, maka perlu dilakukam rekonstruksi kembali seperti semula, berdasarkan data referensi baik dalam bentuk fisik (data secara tertulis hasil dari penelitian, buku, jurnal, prosiding, dll) maupun non fisik (referensi yang bersifat wacana melalui hasil wawancara). Hal ini sebagai bahan kajian dengan mengkomparatifkan dengan data tertulis untuk menjaga kredibilitas sebuah keakuratan data; d) Revitalisasi, merupakan sebuah upaya menghidupkan kembali dengan usaha revitalisasi untuk menggiatkan dan memfungsikan kembali, sehingga kemungkinan dapat terjadi pergeseran fungsi secara ritual, presentasi estetik, dan hiburan. Tahap ini sebagai onprogress dengan memberikan interpretasi baru, makna baru, impresi baru, dari proses menghidupkan kembali dengan bentuk baru namun tetap memiliki identitasnya yang sejalan dengan zamannya 'ngigelan zaman' (Arthur, 2008: 90); e) Inovasi, sebagai seni tradisi yang dinamis mengikuti perkembangan zaman, kreativitas dapat mencakup segala aspek sehingga dapat memunculkan sebuah akulturasi bentuk baru yang memberikan peluang-peluang untuk berkembang, namun secara kontekstualitasnya tetap dapat dipertahankan nilai-nilai luhur yang dimilikinya.

Digitalisasi menjadi keniscayaan yang pasti di era teknologi informasi saat ini. Digitalisasi memang telah mengisi ruang dan hampir segenap sisi di negeri ini. Seni merupakan salah satu cabang ilmu yang telah 
dimasuki oleh digitalisasi. Pada era 4.0 seni sudah sangat berkembang pesat hingga muncul banyaknya pameranpameran seni digital, film animasi, lukisan-lukisan digital dan sebagainya. Teknologi digital di masa kini semakin canggih ini membuat perubahan besar terhadap dunia, lahirnya berbagai macam teknologi digital yang semakin maju telah banyak bermunculan. Berbagai kalangan telah mudah dalam mengakses suatu informasi melalui banyak cara, serta dapat menikmati fasilitas dari teknologi digital dengan bebas dan terkendali khusunya bagi kaum milenial. Digitalisasi budaya dapat diterapkan untuk mengenalkan dan melestarikan kebudayaan Indonesia di era digitalisasi dewasa ini. Digitalisasi budaya merupakan suatu konsep pemanfaatan teknologi informasi dan komunikasi sebagai sarana utama untuk mengelola, mendokumentasi, penyebaran informasi serta memelihara suatu kebudayaan. Berangkat dari hal inilah, penulis akan membahas mengenai seni tradisi serta seni digital, antara konservasi dan inovasi dalam sebuah kebudayaan pada era digitalisasi.

\section{METODE PENELITIAN}

Metode yang digunakan pada penelitian ini adalah metode kuantilatif, yang memadukan antara metode kuantitatif dan kualitatif. Penelitian dilakukan dalam dua tahap, yaitu tahap kuantitatif kemudian kualitatif. Dalam ilmu Desain Komunikasi Visual dapat dilakukan penelitian gabungan, agar data dan hasil analisis kuantitatif digunakan untuk memfasilitasi penelitian kualitatif. Metode kuantitatif membantu mendefinisikan pola penggunaan foto green screen profil penari Papua, Sunda, dan Aceh; sedangkan metode kualitatif digunakan untuk memberikan deskripsi yang kuat dan eksploratif tentang bahasa visual yang digunakan pada foto green screen profil penari Papua, Sunda, dan Aceh. Variabel penelitian adalah (a) Foto profil green screen sebagai independent variable yaitu penari Papua, Sunda, dan Aceh; dan (b) Foto Personal branding green screen sebagai dependent variable yaitu AR Pasua $P A$.

Objek penelitian adalah foto green screen profil Tari Wor Papua yang ditarikan secara rampak berkelompok yang dibuat secara virtual art dan realtime dengan synchronization, sedangkan Tari Cikeruhan yang ditarikan secara berpasangan antara ronggeng (penari perempuan) dan pamogor (penari laki-laki), selanjutnya Tari Guel ditarikan oleh penari tunggal. Secara komposisi dan keharmonian tari dari ketiga wilayah ini bervariatif dalam penyajiannya.

Berdasarkan trikotomi seni, yang memaparkan bahwa hubungan antara seni dan penelitian terdiri atas tiga hal yang secara krusial yaitu: penelitian dalam seni (research on the art), penelitian untuk seni (research for art), dan penelitian melalui seni (research in art). Seni pertunjukan telah menjadi sebuah disiplin ilmu yang mencoba menerapkan berbagai kajian dan metodologi yang integratif. Penelitian ini merupakan ekranisasi sebuah transformasi estetik seni pertunjukan sebagai sebuah disiplin ilmu mencoba dikembangkan dengan berbagai metode dan teorinya yang dikaitkan dengan industri digital.

Penelitian ini adalah penelitian kualitatif dengan pendekatan komparasi morfologi visual. Pendekatan komparasi morfologi visual adalah studi perbandingan bentuk visual motif gerak Tari Papua, Tari Sunda, dan Tari Aceh. Bentuk visual AR Pasua PA terdiri atas elemen visual utama, isen, pendukung dan struktur atau sistem pengorganisasian elemen visual. Vokabuler elemen visual dan sistem pengorganisasianya menghasilkan variasi motif AR Pasua PA. Melalui komparasi morfologi terhadap beberapa jenis motif parang diharapkan dapat diketahui ragam variasi aspek visualitasnya. Variasi motif AR Pasua PA inilah yang digunakan dalam memvalidasi dan menjustifikasi inovasi seni, inovasi seni digital AR Pasua PA.

Morfologi visual adalah unsur visual yang terdiri atas motif, ragam hias, komposisi, dan warna (Ciptandi, Sachari, Haldani 2016: 263). Morfologi visual AR Pasua PA adalah studi tentang pembentukan motif etnik Pasua, cara-cara motif augmented reality Pasua baru diciptakan, dan cara membentuk variasi motif Pasua. Melalui pendekatan ini variasi motif AR Pasua PA dapat dianalisis secara morfologis. Analisis morfologi cukup kompleks karena motif Pasua terdiri atas berbagai bentuk visual motif utama, bentuk visual motif isen, bentuk visual motif pendukung, pola, dan teknik pembuatan motif Pasua. Analisis morfologi adalah proses memecah motif AR Pasua PA ke dalam bentuk atau bagian motif Pasua. Analisis morfologi didasarkan pada jenis motif AR Pasua PA yang ada.

\section{ANALISIS DAN INTERPRETASI DATA}

Kesenian Wor merupakan koreografi dari identitas seorang penari yang menjadi ciri khas dirinya yang tidak dimiliki oleh penari yang lain yang ada di Tanah Papua. Tari Cikeruhan dari Sunda, dan Tari Guel dari Aceh. Ketiga tarian ini sebagai model koreografi tari tradisi, namun tidak lepas dari kreativitas, yaitu mengemukakan sesuatu hal yang selalu baru, segar, dan terus mengalir dalam perekonstruksiannya. Oleh karena itu, kreativitas ketiga tarian ini tidak lepas dari hal-hal seperti gerak tubuh tanpa partitur, tanpa teks, tanpa instrumen, tanpa tradisi, tanpa reportoar, tanpa titik puncak pencapaian, tanpa aturan yang ketat, tanpa acuan yang riil, dan tanpa retorika yang menjadi identitas pribadi seorang penari. Kreativitas dalam Tari Wor, Tari Cikeruhan, dan Tari Guel, tidak dapat terlepas dari pengaruh baik yang bersifat eksternal maupun internal yang akan menentukan arah, bentuk, strategi, dan ekspresi di dalamnya. AR Pasua PA adalah penciptaan koreografi seni digital visual art dan realtime secara synchronization. 
Dengan perkembangan teknologi industri, komunikasi dan informasi pada zaman global sekarang ini, semakin memperbesar peluang terjadinya pertemuan dan persinggungan budaya antar bangsa. Saling mempengaruhi, saling menggunakan, saling bercampur, berasimilasi, serta kerjasama antar ISBI Bandung, ISBI Tanah Papua, dan ISBI Aceh. Seni tradisi yang ada di Papua, Sunda, dan Aceh yang biasa difungsikan di masyarakat sebagai milik masyarakat, menjadi berubah, bahkan sebagian masyarakat seakan tidak memerlukan lagi, akibatnya banyak yang hilang nyaris punah. Kondisi ini merupakan realitas sosial dan budaya yang tidak bisa dihindari, yang mempengaruhi hampir seluruh sendi kehidupan masyarakat, karena itu perlu adanya upaya-upaya yang telah disebutkan pada penjelasan sebelumnya, agar kesenian yang tetap bertahan bahkan berkembang dengan memanfaatkan teknologi di era industri pertunjukan 4.0 ini.

\section{Konservasi dan Inovasi Seni Digital AR Pasua PA di Era Industri 4.0}

Di era seni pertunjukan 4.0 sesuai dengan issu Kemenristekdikti melalui penelitian hibah konsorsium ini, mengkaji sebuah seni tradisi dengan sebuah inovasi seni yang dilakukan dengan menggunakan aplikasi Augmented Reality (AR) Pasua PA, sebagai salah satu alternatif dalam mengapresiasi Tari Wor, Tari Cikeruhan, dan Tari Guel melalui sinkroniasi antara virtual art dan realtime secara bergantian. Terlebih pada beberapa tahun ini kegiatan kolaborasi seni budaya, serta karya seni multimedia, multifungsi dan multikultur semakin banyak dilakukan oleh berbagai pihak, dan seolah-olah telah menandai zaman global ini. Tantangan globalisasi telah dilihat sebagai setting historis penting yang membutuhkan penyesuaianpenyesuaian. Kini kebudayaan telah meningkat secara signifikan, baik secara kuantitas maupun kualitasnya dengan berbagai jenis ragamnya dan bentuk coraknya.

Semua itu menyebabkan seni tradisional harus berhadapan dengan kompleksitas percaturan dunia global. Begitu pula halnya dengan pertumbuhan ekonomi industri, khususnya dalam sektor pariwisata, telah memotivasi perkembangan unit-unit produksi seni. Kondisi ini mengakibatkan kecenderungan pada peningkatan produk-produk seni kemasan yang bersifat instan atau kebutuhan pasar lebih dominan, demikian pula seni pertunjukan lebih cenderung mengedepankan hiburan atau kebutuhan entertaiment, serta berubahnya seni pertunjukan sakral ke pertunjukan profan.

Seni pertunjukan dan kehidupan berkesenian baik yang ada di Papua, Sunda, dan Aceh pada umumnya merupakan salah satu perilaku budaya manusia, baik secara individu maupun sebagai sebuah kelompok masyarakat. Maka dari itu, setiap bentuk seni/kesenian memiliki fungsinya masing-masing dalam kehidupan masyarakat. Hal ini sebagaimana pendapat R.M. Soedarsono dalam tulisannya memaparkan, bahwa setiap zaman, setiap etnis, setiap lingkungan masyarakat, serta setiap bentuk seni pertunjukan memiliki fungsi primer dan sekunder yang berbeda (Soedarsono, 2001: 170). Fungsi primer seni pertunjukan, adalah apabila seni tersebut jelas siapa penikmatnya. Secara garis besar Soedarsono menyatakan, bahwa seni pertunjukan memiliki tiga fungsi primer, yaitu: (1) sebagai sarana upacara; (2) sebagai ungkapan pribadi; dan (3) sebagai presentasi estetis. Adapun fungsi sekunder apabila seni pertunjukan bertujuan bukan untuk dinikmati, tetapi untuk kepentingan yang lain. Ini berarti fungsi pertunjukan menjadi multifungsi, tergantung dari perkembangan masyarakat pendukungnya. Multifungsi itu antara lain; sebagai pengikat kebersamaan, media komunikasi, interaksi, ajang gengsi, bisnis, dan mata pencaharian. Artinya fungsi belum tentu abadi dari waktu ke waktu (Royce, 1980: 85).

Sebagaimana juga pendapat Janet Wolff dalam bukunya berjudul The Social Production of Art mengungkapkan, bahwa perkembangan seni tidak bisa lepas dari masyarakat pendukungnya. Dengan kata lain, seni merupakan produk sosial (Wolff, 1993: 26-48). Pendapat Wolff tersebut seperti juga halnya pandangan Arnold Hauser dalam tulisannya berjudul The Sociology of Art dengan bahasan khusus Art as a Product of Society dan Society as the Product of Art, mengungkapkan bahwa seni sebagai produk masyarakat tidak lepas dari adanya berbagai faktor sosial budaya, yaitu faktor alamiah dan faktor generasi, yang semuanya memiliki andil bagi perkembangan seni (Hauser, 1982: 94328). Artinya, seni tumbuh dan berkembang lebih banyak merupakan hasil ekspresi dan kreativitas masyarakat pemiliknya. Masyarakat dan seni merupakan kesatuan yang satu sama lain saling terikat dan berkaitan. Oleh karenanya hadirnya sebuah kelas atau golongan tertentu, akan menghadirkan gaya seni yang tertentu pula sesuai dengan bentuk masyarakat yang ada pada saat itu.

Sejalan dengan pendapat Hauser, bahwa masyarakat dan seni merupakan kesatuan yang satu sama lain saling terikat dan berkaitan, gejala ini merupakan 'sistem sosial' sebagaimana yang telah dikembangkan oleh Talcot Parson dan para pengikutnya yang di antaranya mempunyai anggapan dasar, yaitu: (1) masyarakat haruslah dilihat sebagai suatu sistem daripada bagian-bagian yang saling berhubungan satu sama lain; (2) dengan demikian hubungan saling mempengaruhi di antara bagian-bagian tersebut adalah bersifat ganda dan timbal balik; dan (3) sistem nilai tersebut tidak saja merupakan sumber yang menyebabkan berkembangnya integrasi sosial, akan tetapi sekaligus juga merupakan unsur yang menstabilisasi 'sistem sosial' budaya itu sendiri.

Alison Bracker (ed) (2009) mengartikan konservasi sebagai suatu proses kompleks dan terus-menerus yang melibatkan penentuan mengenai apa yang dipandang sebagai warisan, bagaimana ia dijaga, bagaimana ia digunakan, oleh siapa, dan untuk siapa. Istilah konservasi memiliki cakupan yang 
luas karena tidak hanya digunakan pada satu disiplin ilmu saja. Istilah konservasi digunakan dalam bidang biologi (conservation biology), kedokteran (conservation genetics and conservation sequence), hukum (conservation laws), energi (energy conservation), air (water conservation), habitat tumbuhan dan hewan (habitat conservation), tanah (soil conservation), kelautan (marine conservation), arsitektur (architectural conservation), dan kebudayaan (conservation - restoration). Menurut kamus besar Bahasa Indonesia, konservasi adalah pelestarian; pemeliharaan dan perlindungan sesuatu untuk mencegah kemusnahan (kerusakan dan sebagainya) dengan cara pengawetan.

Dalam bidang cagar budaya juga digunakan istilah konservasi. Secara umum, konservasi cagar budaya sebenarnya memiliki cakupan yang luas dan bisa diartikan sebagai pelestarian atau perlindungan itu sendiri. Dalam Undang-undang No. 11 Tahun 2010 tentang Cagar Budaya tidak disebutkan istilah konservasi, tetapi lebih menggunakan istilah pelestarian atau pelindungan. Menurut Undang-undang Nomor 11 Tahun 2010 tentang Cagar Budaya, pelestarian adalah upaya dinamis untuk mempertahankan keberadaan cagar budaya dan nilainya dengan cara melindungi, mengembangkan, dan memanfaatkannya. Sedangkan pelindungan adalah upaya mencegah dan menanggulangi dari kerusakan, kehancuran, atau kemusnahan dengan cara penyelamatan, pengamanan, zonasi, pemeliharaan, dan pemugaran cagar budaya. Dalam undang-undang tersebut dijelaskan bahwa cagar budaya dapat berupa benda cagar budaya, bangunan cagar budaya, struktur cagar budaya, situs cagar budaya, dan kawasan cagar budaya. Mengacu pada makna konservasi secara luas, lingkup konservasi berarti tidak hanya terbatas pada konservasi benda atau konservasi bangunan, tetapi bisa saja sampai konservasi kawasan.

Sementara itu, dalam lingkup yang lebih sempit, konservasi dapat diartikan sebagai tindakan pemeliharaan, pengawetan, atau treatment tertentu yang diaplikasikan pada material cagar budaya. Secara internal di Balai Pelestarian Cagar Budaya Sumatera Barat, pemahaman konservasi cagar budaya lebih cenderung pada kegiatan teknis atau pemeliharaan terhadap material cagar budaya. Kegiatan ini lebih difokuskan pada upaya untuk membersihkan cagar budaya dari faktor penyebab kerusakan dan pelapukan dan upaya mengawetkan material cagar budaya agar tidak terjadi degradasi lebih parah. Inovasi sebagai suatu gagasan baru yang diterapkan untuk memprakarsai atau memperbaiki suatu produk atau proses dan jasa. Inovasi berarti memunculkan sesuatu yang baru sesuatu yang belum ada dan berbeda dari sesuatu yang sudah ada sebelumnya. Inovasi dapat berarti melahirkan sesuatu ataupun menyempurnakan sesuatu. Dalam hal budaya, inovasi dapat berarti memunculkan sebuah kesenian yang baru, ataupun mengemas sebuah seni tersebut dengan sesuatu yang baru yang belum pernah di lakukan sebelumnya. Atau memodifikasi sebuah seni agar relevan dengan perkembangan zaman, juga mengubah tujuan atau peruntukan sebuah seni tersebut ke arah yang lain.

Sebagaimana tujuan penelitian konsorsium ini, telah menetapkan 3 sampel pertunjukan tari dari 3 daerah yang berbeda, serta kelompok masyarakat yang berbeda, yaitu Tanah Papua, Tanah Parahyangan, Aceh Serambi Mekah, maka sebelum dilakukan pengemasan dengan media baru secara seni digital yang dapat digunakan untuk sajian pertunjukan, pariwisata, atau bahan ajar. Adapun potensi AR Pasua PA meliputi:

\section{Kearifan lokal Seni Tradisional Papua}

Papua merupakan salah satu provinsi di wilayah Indonesia yang sangat kaya akan seni tradisional. Sebagai salah satu refleksi kebudayaan lokal, seni tradisional di Papua mencirikan latar budaya dan nilai-nilai filosofis dalam masyarakat adat yang sarat nilai dan makna. Selain itu, adaptasi masyarakat dengan alam sekitarnya hidup juga turut mempengaruhi corak dan karakteristik seni tradisional yang diciptakan dan diwariskan secara turun temurun hingga sekarang. Tidak hanya tentang berburu atau berperang, terciptanya berbagai jenis seni tradisional Papua juga bersumber dari religi atau mitologi lokal masyarakat serta refleksi kehidupan masyarakat di alam sekitar dimana nilai filosofis dan pemaknaannya tertuang ke dalam berbagai wujud kesenian seperti tarian tradisional, nyanyian adat, alat musik, kerajinan tangan, ukiran, hingga seni lukisan dan patung.

Secara material, seni tradisional Papua sungguh sangat kaya ragam jenisnya. Dari seni pertunjukan, Papua memiliki banyak jenis tarian seperti tari bertema kepahlawanan yang terinspirasi dari perang, tari bertema alam dan aktivitas sosial yang terinspirasi dari berburu, tari bertema kebersamaan seperti tari penyambutan dan tari rakyat, serta tarian yang bertema religi dan mitologi seperti tarian ritual dan tari-tari sakral. Gerakan tari membangkitkan rasa keindahan karena dirancang tidak hanya sekedar menghadirkan gerak maknawi. Oleh karena alat ungkapnya adalah tubuh manusia, maka keindahan badani atau sensuous beauty menjadi salah satu daya pikat berbagai jenis tarian (Rustiyanti, 2017: 225). Dari seni musik, Papua memiliki alat musik tradisional yang bernama tifa dan $f u$ (sejenis kerang laut yang dibunyikan dengan cara ditiup). Kedua alat musik ini memiliki ragam bentuk dan motif hiasan yang beragam antar wilayah adat di Papua sehingga keunikan identitasnya juga semakin kuat. Dari seni ukir, Papua dikenal memiliki ragam gaya ukiran khas dimana salah satu yang terkenal adalah ukiran gaya Suku Asmat.

Dari seni patung, Papua juga memiliki keunikan yang khas dari wujud figur patung yang dimiliki masing-masing wilayah adat. Beberapa di antaranya adalah Patung Amfyanir dari Biak, Patung Mbis dari Kabupaten Asmat, 


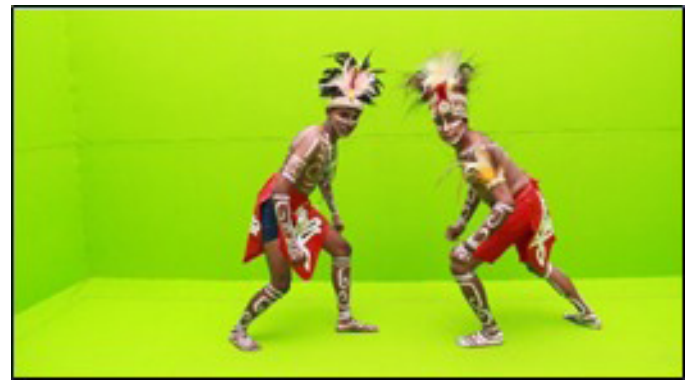

Gambar 1. Penari Karwar laki-laki (Papua)

Dokumentasi: Tim Peneliti KRUPT 2019.

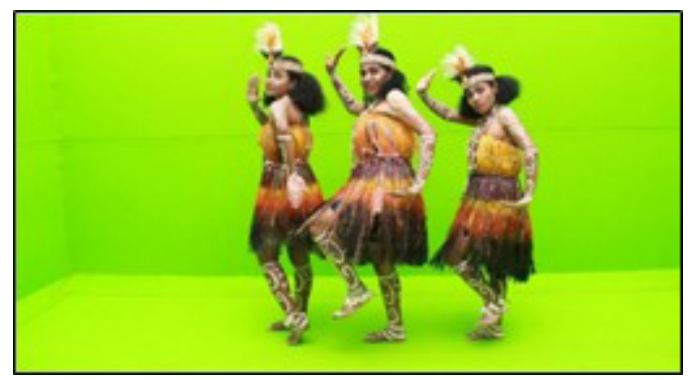

Gambar 2. Penari Karwar perempuan (Papua) Dokumentasi: Tim Peneliti KRUPT 2019.

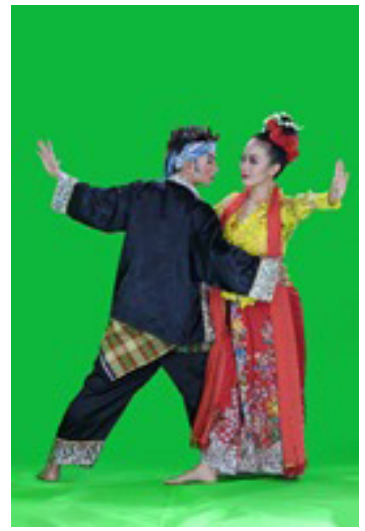

Gambar 3. Tari Cikeruhan berpasangan (Sunda) Dokumentasi: Tim Peneliti KRUPT 2019.

Patung Mbitoro dari Suku Kamoro dan Patung Doreri Uno yang kini tengah menghadapi kepunahan karena krisis regenerasi. Masing-masing patung tersebut memiliki wujud figur dan makna filosofi khas serta dihormati dalam kebudayaan lokal masyarakat masing-masing wilayah. Namun satu hal yang memiliki kemiripan, ialah patungpatung tersebut sama-sama menggambarkan konsep penghubung kehidupan dan kematian.

Dari segi kerajinan tangan, salah satu seni tradisional Papua yang dianggap sebagai kebudayaan universal di Tanah Papua adalah noken. Tas tradisional yang dibuat dengan cara dirajut ini tak hanya sebatas benda yang digunakan untuk membawa barang, namun memiliki makna filosofis kehidupan yang mendalam. Seorang perempuan Papua dikatakan sudah dewasa apabila telah bisa membuat sebuah noken. Bahkan di beberapa wilayah tertentu, sebelum bisa membuat sebuah noken, seorang wanita belum diijinkan untuk menikah.
Selain dari segi material, Papua juga memiliki kekayaan destinasi tempat wisata dan situs budaya yang potensial dijadikan tempat atraksi seni tradisional. Penataan tempat-tempat wisata/situs budaya populer seperti Situs Prasejarah Megalitikum Tutari di Kabupaten Sentani, Goa Jepang di Biak, Kampung Asei di Pulau Asei di tengah Danau Sentani yang terkenal dengan kerajinan lukisan di atas kulit kayu serta pembuatan gerabah di Kampung Abar, wilayah Kabupaten Sentani yang telah dilakukan oleh pemerintah provinsi maupun daerah perlu diimbangi dengan pemberdayaan seni-seni tradisional setempat sehingga dapat menjadi nilai tambah promosi pariwisata Papua ke depannya.

Keberlimpahan material seni tradisional dan ketersediaan tempat-tempat wisata/situs budaya kurang terasa cukup jika belum ada ketersediaan ruang tampil bagi seni tradisional. Adanya festival-festival tahunan yang diadakan di berbagai tempat seperti Festival Lembah Baliem di Pegunungan Wamena, Festival Danau Sentani di wilayah Kabupaten Sentani, serta Festival Munara Wampasi di Biak merupakan harapan yang menjanjikan bagi ruang hidup seni tradisional. Jika potensi keindahan alam dan destinasi wisata Papua mampu berpadu dengan keunikan seni tradisionalnya, maka Papua diyakini akan mampu menjadi daftar tujuan favorit para wisatawan asing yang datang ke Indonesia.

Terlepas dari segala kekuatan potensi tersebut di atas, sesungguhnya Papua memiliki hambatan yang mendasar dalam usaha pelestarian seni tradisionalnya. Salah satunya adalah pewarisan (transfer of knowledge) seni tradisional yang dominan bersifat lisan dan otodidak. Beberapa bentuk kesenian seperti Tari Ibhea Obhea di Kampung Doyo Lama, Kabupaten Sentani yang mengalami krisis regenerasi penari serta ragam motif body painting dalam budaya tari Suku Padaido di Kabupaten Biak-Numfor yang pernah dieliti oleh Peradantha (2019), menunjukkan hambatan yang sama, yaitu pewarisan keseniannya masih bersifat lisan dan aspek verbal maupun non-verbal kesenian tersebut hanya diketahui oleh para seniman generasi tua. Untuk itulah, penelitian tentang seni pertunjukan maupun seni rupa dan kerajinan tangan tradisional Papua hingga saat ini masih perlu diperbanyak, terutama seni-seni tradisional yang ada di kampung-kampung pedalaman. Selain itu, kurangnya sinergitas antara pemerintah provinsi/daerah dengan seniman dari kampung-kampung adat serta tempat-tempat wisata/situs budaya juga menjadi persoalan yang harus dipecahkan bersama.

Tentunya, selalu ada peluang di setiap hambatan yang dihadapi. Dalam upaya penyelamatan dan pengembangan seni tradisional Papua, terobosan inovatif perlu dilakukan dan diperbanyak sehingga peluang memecahkan masalah yang dihadapi juga semakin besar. Salah satu terobosan inovatif dalam penyelamatan seni tradisional Papua adalah digitalisasi seni tradisional. Knoll (dalam Ling \& Julisiono, 


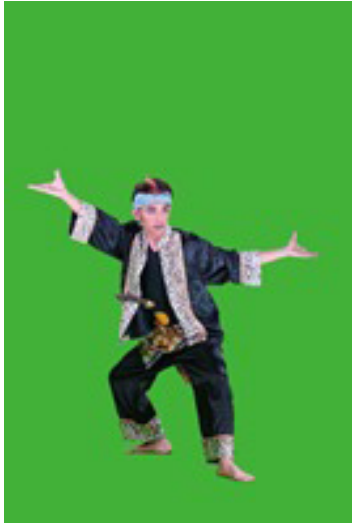

Gambar 4. Penari Cikeruhan laki-laki (Sunda) Dokumentasi: Tim Peneliti KRUPT 2019.

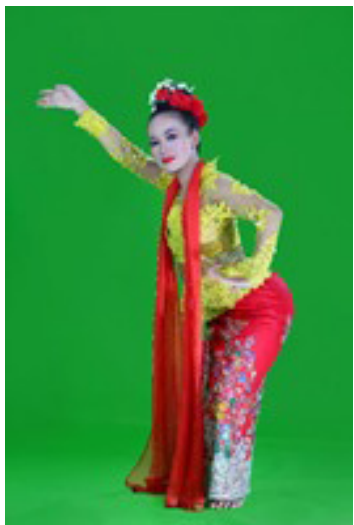

Gambar 5. Penari Cikeruhan perempuan (Sunda) Dokumentasi: Tim Peneliti KRUPT 2019.

2018: 145) menyatakan bahwa seni digital adalah seni baru yang menggunakan teknologi komputer dalam pembuatan dan penyajian akhirnya. Sitokdana (2015: 102) mengungkapkan telah ada beberapa aplikasi digital yang diciptakan untuk mempermudah sekaligus menarik minat para pembaca untuk mempelajari suatu kesenian. Beberapa di antaranya seperti e-Gamelan, yaitu suatu aplikasi untuk pembelajaran gamelan Kyai Sri Kuncoro Mulyo Lokananta Surakarta Gamelan untuk perangkat digital berbasis iOS, kemudian ada aplikasi Angklung Digital yang diluncurkan oleh PT. Pazia Pillar Mercycom, yaitu aplikasi bermain gamelan angklung secara virtual untuk perangkat digital berbasis Android. Kiranya jenisjenis digitalisasi seperti ini perlu lebih dikembangkan untuk seni tradisional Papua karena ada banyak kesenian yang menunggu untuk diselamatkan sebelum terlambat.

Penerapan digitalisasi seni tradisional Papua kiranya akan membawa angin segar bagi para seniman dan masyarakat di tengah isu ancaman kemandegan regenerasi seni di beberapa wilayah. Dengan masuknya Papua ke era digital art, maka segala deskripsi seni, makna-makna simbolik dan filosofi suatu kesenian dapat dimuat dalam aplikasi yang diciptakan sesuai bentuk seni masingmasing. Terlebih bagi seni tari yang vokabulasi gerak tari menuntut pembelajaran secara praktek ketubuhan yang tidak maksimal termuat dalam pembelajaran melalui buku konvensional. Namun jika diberikan sentuhan digital art, maka pembelajaran melalui program aplikasi Augmented Reality misalnya akan banyak membantu mempelajari sebuah seni tari berkat bantuan gawai yang mendukung aplikasi tersebut.

\section{Kearifan Lokal Seni Tradisional Sunda}

Konsep garap konten seni pertunjukan Sunda mengambil inspirasi dari Tari Sunda dengan mengangkat Tari Cikeruhan dari tradisi ritual panen padi sebagai wujud rasa syukur kepada Dewi Sri Pohaci (dewi kesuburan). Penari virtual tari Cikeruhan dipertunjukan secara berpasangan penari putri dan penari putra yang termasuk dalam rumpun tari Sunda Jaipong berpasangan. Secara langsung penari dengan aplikasi AR Pasua PA diiringi musik tifa dari Papua dan Musik Rapai dari Aceh. Tari Cikeruhan memiliki ciri khas tersendiri, di mana unsur gerak ketuk tilu atau pencak silat lebih dominan pada gerakan kaki.

Konsep garap Tari Cikeruhan merupakan tradisi ritual panen padi sebagai wujud rasa syukur kepada Dewi Sri Pohaci (dewi kesuburan). Penari virtual tari Cikeruhan dipertunjukan secara berpasangan penari putri dan penari putra yang termasuk dalam rumpun tari Sunda Jaipong berpasangan. Tari Cikeruhan sebagai salah satu bentuk wisata budaya dan wisata digital, sehingga pariwisata dapat berkembang sebagai komunikasi yang semakin meluas antara komponen-komponen lain dalam kerangka hubungan yang bersifat saling mempengaruhi. Dampak yang diakibatkan oleh pariwisata tersebut terhadap aspek sosial, budaya, ekonomi dan alam lingkungan dapat menjadi dampak positif dan dampak negatif (Geriya, 1996: 38).

Seni digital $A R$ tari Cikeruhan sebagai salah satu bentuk wisata digital, adalah dengan mengapresiasi green screen tari Cikeruhan melalui aplikasi augmented reality, sehingga diperoleh pemahaman ethno-estetik tari Cikeruhan. Pemahaman tari Cikeruhan mempunyai makna sebagai wisata budaya, adalah: 1) Gerak atau kegiatan wisata yang dirangsang oleh adanya objek-objek wisata yang berwujud hasil-hasil seni budaya setempat (Papua-Sunda-Aceh); 2) Adat istiadat, upacara agama, tata hidup masyarakat, peninggalan sejarah, hasil seni, kerajinan-kerajinan rakyat dan sebagainya.

Proses yang turun temurun tari Cikeruhan dipelajari baik secara formal, informal, maupun nonformal dari pihak guru kepada murid, dari orang tua kepada anak, dari saudara kepada saudara, dari teman kepada teman dan lain sebagainya. Apa pun bentuknya proses tersebut sering disebut sebagai pewarisan. Dengan mempelajari budaya, suatu kelompok budaya dapat mewariskan ciri-ciri perilaku kepada generasi selanjutnya melalui mekanisme belajar-mengajar, yang juga melibatkan penurunan ciri-ciri budaya orang tua kepada anak-cucu. 
Dalam pewarisan tegak (vertical transmission), orang tua mewariskan keterampilan, nilai, keyakinan, motif budaya, dan sebagainya kepada anak-cucu. Dalam kasus ini, sulit membedakan 'pewaris budaya' dengan 'pewaris biologi'. Secara khas, seseorang belajar dari siapa saja yang merasa bertanggungjawab terhadap konsepsinya. Jadi, tetap saja orang tua biologis dan orang tua budaya adalah sama (Berry, 1999: 32). Dengan demikian faktor keturunan dan faktor lingkungan berinteraksi terus menerus dalam membentuk perkembangan dan kepribadian seseorang. Pada waktu terjadinya janin, faktor keturunan telah memprogramkan potensi-potensi manusiawinya untuk kelak kemudian menjadi manusia. Pada waktu yang bersamaan faktor lingkungan juga turut mempengaruhi pembentukan janin. Faktor lingkungan dan faktor keturunan secara bersamasama memberikan bentuk kepada perkembangan ketika janin yang telah dilahirkan tumbuh dan berkembang menjadi anak terus sampai pada masa dewasanya.

Ada dua aspek yang melekat pada tari Cikeruhan untuk dikaji, yaitu aspek material dan immaterial. Aspek material adalah suatu objek yang dapat secara langsung disentuh (tangible) dalam kontak fisik. Analisis tari dipandang dari bentuk atau teks dapat dilakukan dengan menganalisis bentuk struktur, teknik, dan gaya secara koreografis, beserta aspek-aspek keberadaan bentuk tari (Rustiyanti, 2014: 221), sedangkan aspek immaterial adalah sesuatu yang tidak bisa disentuh (intangible) dalam kontak fisik. Aspek pertama bereksistensi pada wilayah perilaku (behavioral aspect), sedangkan aspek kedua berada pada wilayah mental (mental aspect). Edmund Husserl dalam pemikiran phenomenlogy seperti dijelaskan Jonathan H. Turner berpandangan, bahwa apa yang teramati (out there) atau berada pada wilayah perilaku, sesungguhnya merupakan pancaran dari kesadaran mental (mental consciousness) berupa pengetahuan (1978: 395). Pada hakikatnya, perilaku itu adalah pancaran dari pengetahuan orang yang berpengetahuan tersebut, baik pengetahuan yang terbentuk ke dalam suatu sistem maupun pengetahuan tidak terbentuk ke dalam suatu sistem.

\section{Kearifan Lokal Seni Tradisional Aceh}

Kebudayaan menjadi dasar dalam memahami hasil karya manusia yang tertuang dalam berbagai unsur dan salah satu nya adalah bukti peningalan sejarah.Unsurunsur kebudayaan itu sendiri secara universal terbagi dalam tujuh unsur yaitu; sistem agama dan upacara keagamaan, sistem organisasi masyarakat, sistem pengetahuan, bahasa, kesenian, sistem mata pencarian hidup, dan sistem teknologi, (Koentjaraningrat. 2004). Keseluruhan unsur ini kemudian menjadi landasan dalam kehidupan masyarakat untuk dijalani dalam berbagai aspek kehidupan, dengan berbagai bentuk aktivitas dalam kehidupan social masyarkat. Kebudayaan ini juga berfungsi dalam menentukan norma, perilaku yang teratur serta meneruskan adat dan nilai-nilai kebudayaan, sesuai dengan kebutuhan dari masyarakatnya.
Hal ini akan menyebabkan terjadinya perbedaan dalam pelaksanaan dari aktivitas yang dilakukan dan menyebabkan setiap kelompok masyarakat akan melahirkan kebudayaan dan adat-istiadat yang berbedabeda. Memiliki peninggalan warisan budaya yang berbeda dan pola hidup dan tingkah laku yang beragam menjadikan struktur pola pikir masyarakat yang plural, baik mitos maupun sistem nilai dari setiap masyarakatnya dalam menghasilkan suatu unsur kebudayaan yang tidak sama. Sehingga dapat mempererat ikatan solidaritas, dan menjadi ciri dan pembeda dari masing-masing kelompok masyarakat.

Setiap daerah yang ada di Indonesia mempunyai ragam seni pertunjukan, Seni pertunjukan biasanya ditampilkan secara monoetnik atau satu jenis kesenian untuk masyarakat tertentu sebagai cerminan dari budaya masingmasing daerah dan masyarakatnya. Disharmoni antar suku, budaya, ras dan agama merupakan polemik kebangsaan yang tengah terjadi pada masyarakat Indonesia saat ini. Memudarnya pengamalan kebhinnekaan yang disertai penurunan nilai-nilai kebangsaan adalah ancaman bagi kesatuan Republik Indonesia. Oleh karenanya perlu motivasi dan media dalam pengamalan nilai persatuan dan kesatuan sebagai wujud syukur serta hikmat atas keberagaman suku, budaya, ras dan agama di Indonesia sebagai negara majemuk atau multiculturalism nationstate. Kemajemukan seni pertunjukan di Indonesia dapat dijadikan ruang kolaborasi dalam penelitian yang dilaksanakan oleh tim konsorsium dari tiga perguruan tinggi di tiga wilayah Indonesia : Barat, Tengah dan Timur ini diberi tajuk Augmented Reality PaSuA (Papua-SundaAceh) Performing Art (AR Pasua PA). Masing-masing perguruan tinggi dalam tim ini menciptakan proyek digitalisasi seni tari melalui bantuan teknologi Augmented Reality (AR). Multiculturalismem nasionstate ini akan di presentasikan dalam penciptaan karya seni pertunjukan dengan menjadikan augmented reality sebagai media pembelajarannya. Pengembangan augmented reality dalam penciptaan seni pertunjukan 4.0 menggambarkan tentang siklus kehidupan manusia yang disimbolkan dengan Matahari. Matahari terbit di Papua selanjutnya bersinar di tanah Parahyangan, Sunda dan akhirnya terbenam di Aceh, Serambi Mekah. Tujuannya penelitian ini adalah mengembangkan pasar industri kreatif mixed augmented reality dalam pertunjukan seni nusantara. Metode eksperimen dan observasi virtual melalui media virtual. Tahapan intensitas komunikasi untuk menggali kemutakhiran data, kecenderungan seni pertunjukan, proses kreatif penciptaan seni, dihadirkan kembali dalam konsep baru yang disebut AR Pasua PA.

Penggunaan augmented reality dalam garapan juga menjadi nafas baru dalam pemanfaatan teknologi sebagai ruang eksperimental dalam proses penciptaan karya baru seni pertunjukan ataupun media pembelajaran khususnya kesenian Aceh. Kreativitas dalam pembuatan Augmented 


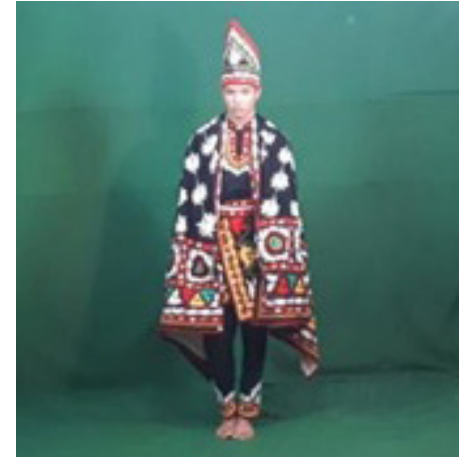

Gambar 6. Penari Guel (Aceh)

Dokumentasi: Tim Peneliti KRUPT 2019.

Reality (AR) Pasua PA merupakan proses kreatif seni pertunjukan dengan mendigitalisasikan karya seni Pasua, berdasarkan pandangan Murgiyanto bahwa memelihara tradisi bukanlah sekedar memelihara bentuk tetapi lebih pada jiwa dan semangat atau nilai-nilai, maka kita akan dengan lebih leluasa bisa melakukan interpretasi dan menciptakan kembali, sekaligus kita juga akan mewarisi sikap kreatif dan imajinasi yang subur sebagaimana dimiliki nenek moyang kita yang telah berhasil menciptakan karyakarya besar di masa lampau. Dengan demikian, kita akan selalu dapat menyelaraskan semangat kesenian tradisi dengan perkembangan kehidupan masyarakat pada masa sekarang (2004:16).

Proses penciptaan ISBI Aceh dimulai pada bulan MeiAgustus 2019 bertempat di ISBI Aceh. Proses penciptaan diawali dari riset tentang seni pertunjukan di Aceh dan fokus pada tari saman, teater tutur dan guel. Penciptaan karya konsorsium PT Seni ini awalnya akan merangkai pertunjukan dari papua, sunda dan Aceh, namun kemudian berkembang menjadi media pembelajaran seni pertunjukan dan konsentrasi terhadap pembuatan AR seni pertunjukan dari suku Gayo di Aceh Tengah yaitu Guel. Adapun khusus dalam uji coba tahap pertama yang akan disandingkan dalam pemograman AR ISBI Aceh memilih Tari Guel sebagai objek Augmented Reality.

Ada beberapa alasan kenapa tari Guel yang menjadi content AR yaitu salah satunya ialah karena tari Guel secara artistik marik yaitu menggunakan kain panjang dengan motif khas suku gayo yang disebut ulen-ulen sebagai handproperty penting yang harus ada dalam tarian. Selain itu Tari Guel belum begitu dikenal masyarakat luas sepertihalnya tari saman. Upaya dalam memperkenalkan seni pertunjukan khas Aceh yang banyak dan beragam. Digitalisasi karya dilakukan pada bulan Agustus 2019. Hasil rekaman mandiri di ISBI Aceh dikirim kepada tim dari ISBI Bandung untuk kemudian diolah di dalam studio ke dalam format Augmented Reality.

\section{SIMPULAN}

Saat ini sudah banyak sekali bermunculan seni-seni yang disampaikan atau di aplikasikan melalui alat-alat digital. Sehingga tak asing apabila seni-seni tersebut dikenal dengan seni digital. Seni digital juga memiliki kelebihan tersendiri dibanding dengan seni yang lain. Yakni bagi pemula yang baru terjun ke dunia seni hanya perlu mengetahui teknik dasar penggunaan suatu program.

Seni digital dalam perkembangan zaman modern ini terlihat sangat mendominasi, terbukti dari banyaknya film animasi, komik digital, gambar-gambar yang dibuat dengan media digital dan sebagainya. Munculnya seni digital bukan untuk menggusur seni tradisional, melainkan berfungsi sebagai media baru untuk melengkapi dan lebih menarik minat pemuda milenial.

Zaman globalisasi hendaknya mampu beradaptasi dengan arus globalisasi yang sedang melanda dunia. Globalisasi memang tidak bisa dihindari. Jika kita menghindari justru akan menjadi manusia yang primitif lagi. Jangan sampai kita tertinggal masalah teknologi dan lain-lain yang berhubungan dengan globalisasi agar tidak tertelan oleh zaman, tetapi sebaiknya selektif terhadap pengaruh globalisasi. Dapat membedakan mana yang memberikan pengaruh baik dan mana yang memberikan pengaruh buruk. Dengan membekali diri kepribadian yang kuat agar tidak mudah begitu saja terpengaruh dengan dampak negatif globalisasi. Menanamkan dan mengamalkan nilainilai Pancasila dengan sebaik-baiknya terutama dengan memperkuat keimanan kita terhadap Tuhan Yang Maha Esa adalah cara terbaik untuk tidak mudah terpengaruh dari arus globalisasi.

Globalisasi bukan suatu alasan punahnya suatu kebudayaan, melainkan dari masyarakat itu sendiri yang terlalu mengedepankan gengsi. Hendaknya baik pemerintah maupun masyarakat harus sadar dan sama-sama saling mengingatkan pentingnya sebuah kegiatan pelestarian budaya. Oleh karena itu, budaya merupakan warisan dan ciri khas dari sebuah bangsa. Budaya bagaikan jatidiri dan wibawa yang melekat dalam sebuah suku bangsa, apabila budaya itu hilang, maka hilang pula jati diri serta wibawa yang dimilikinya.

\section{UCAPAN TERIMAKASIH/PENGHARGAAN}

Ucapan terimakasih dan penghargaan kami sampaikan kepada Kemenristekdikti yang telah mendanai Hibah Penelitian Penugasan KRUPT (Konsorsium Riset Unggulan Perguruan Tinggi) Bidang Seni Pertunjukan 
tahun 2019-2021, Rektor ISBI Bandung, Rektor ISBI

Tanah Papua, dan Rektor Aceh yang telah memberi tugas kepada para peneliti yang terdiri atas 4 orang dosen PT Seni tersebut, serta PT. Assembrl Teknologi Indonesia sebagai Mitra Penelitian. Berkat kerjasama dari semua unsur sehingga dapat terwujud penelitian ini.

\section{DAFTAR RUJUKAN}

Arthur S. Nalan. (2008), “Seni Pertunjukan untuk Semua Orang: Konsep Perlakukan dan Pewarisan", dalam Tradisi sebagai Tumpuan Kreativitas Seni, Sunan Ambu Press, Bandung.

Hauser, Arnold. (1982), The Sociology of Art, The University Press, Chicago and London.

Lauer, Robert H. (1993), Perspektif tentang Perubahan Sosial, Alih bahasa: Alimandan. Rineka Cipta, Jakarta.

Ling, Gabriella Rosely dan Eunike Kristi Julistiono. (2018), "Fasilitas Seni Digital di Surabaya". Jurnal e-Dimensi Arsitektur Vol. VI, NO. 1, (2018), 145-152.

Peradantha, IBG. Surya. (2019), "Pembelajaran Tari Ibea Obhea di Kampung Doyo Lama, Kabupaten Sentani, Papua (Laporan Penelitian), Balai Pelestarian Nilai Budaya (BPNB) Papua, Jayapura.

.(2019), "Makna Simbolik Body Painting dalam Budaya Tari Suku Padaido, Biak-Numfor, Papua”. (Laporan Penelitian), Institut Seni Budaya Indonesia (ISBI) Tanah Papua, Jayapura.

R.M. Soedarsono. (2001), Metodologi Penelitian Seni Pertunjukan. Bandung: Masyarakat Seni Pertunjukan Indonesia.

Royce, Anya Peterson. (1980), The Anthropology of Dance. Indiana University Press, Bloomington dan London.

Rustiyanti, Sri. (2015), “Aluang Bunian Karawitan Minangkabau dalam Pamenan Anak Nagari dari Penyajian Bagurau ke Presentasi Estetik", dalam Journal of Performing Arts Vol. 16 No. 2 Agustus, Fakultas Seni Pertunjukan ISI Yogjakarta.

Rustiyanti, Sri. (2014), "Estetika Randai Analisis Tekstual dan Kontekstual”, dalam Jurnal Mudra Vol 29 No. 2 Mei, ISI Denpasar, UPT Penerbitan.

Rustiyanti, Sri. Listiani, Wanda (2017), "Visualisasi Tando Tabalah Penari Tunggal dalam Photomotion Pertunjukan Rampak kelompok Tari Minang", dalam Jurnal Mudra Vol 32 No. 2 Mei, Pusat Penerbitan LP2MPP ISI Denpasar.
Sitokdana, Melkior N.N. (2015), "Digitalisasi Kebudayaan di Indonesia". Seminar Nasional Teknologi Informasi dan Komunikasi2015 (SENTIKA2015), Yogyakarta, 28 Maret 2015.

Sedyawati, Edi. (1986), Pertumbuhan Seni Pertunjukan, Sinar Harapan, Jakarta.

Seramasara, I Gusti Ngurah. (2017), "Perubahan Kreativitas Seni Sebuah Proses Simbolik Dalam Kategori Sejarah", dalam Jurnal Mudra Vol 32 No 2, Mei 2017, Pusat Penerbitan LP2MPP ISI Denpasar.

Van Peursen. (1976), Strategi Kebudayaan, Kanisius, Yogyakarta.

Wolff, Janet. (1993), The Social Production of Art, New York University Press, Washington Square, New York.

Yoeti, Oka. (2006). Pengantar Ilmu Pariwisata, Angkasa, Bandung. 